\title{
The American Politics of Policing and Incarceration
}

\author{
Jeffrey C. Isaac
}

\begin{abstract}
"Seventeen years ago and still the date, the time of day I arrived, and the exact location of the cell in solitary confinement are permanent fixtures in my memory. I was sixteen years old and being held in pretrial detention on carjacking and robbery charges. After spending three months in juvenile facilities, I had grown strangely familiar with being in a cell. But nothing prepares you for solitary confinement. I spent ten days in that cell. I learned to pace, seven steps back and forth, again and again. I stared at the wall, sought out figures in the cracks. Across from me was the padded room where they sent prisoners who threw things on the deputies. The kid in the cell beside me, he too only sixteen or seventeen years old, told me about all of his fears of a straightjacket. Those days felt like a straightjacket to me. Eight of those days were without a shower or any of the other small allowances that helped men from freezing in the night. I wore the same clothes and slept on a concrete slab that was covered in phlegm. For a time I told myself that the ordeal couldn't be real. I wondered if one of the punishments for guilt was solitary. How would I know otherwise? I hadn't been to court, hadn't seen my lawyer in a few weeks, had yet to have a trial-and yet, without explanation I was in solitary confinement. After those first ten days in solitary, I would go on to plead guilty to carjacking and robbery. Sentenced to eight years in prison, the better part of my youth was spent confined. And during those eight years, I spent a year and a half doing various short stints in solitary confinement. I watched grown men crack under the pressure of a solitary cell. I watched men beg for relief, strapped to a bed by their arms and legs. Seventeen years later, I find that I'm again constantly thinking about solitary confinement. The horror stories that drive the public conversation about solitary are not stories to me, but memories. It's unsettling because as much as I know the truth of what the noise of silence can do to a person's mind, I know the dangers for juveniles are worse.
\end{abstract}

- Reginald Dwayne Betts, "I Was 16 and in Solitary Before I Ever Went to Trial"

"It is said that no one truly knows a nation until one has been inside its jails. A nation should not be judged by how it treats its highest citizens, but its lowest ones."

— Nelson Mandela

$T$ he day I first sat down to draft this Introduction was the day that the city of Baltimore exploded. Most readers will need little background. On April 12, 2015, a 25-year-old African American man named Freddie Gray was stopped by police on the streets of Baltimore, forcibly taken into custody, and thrown, screaming in pain, into a police van. Within hours he arrived at University of Maryland R. Adams Crowley Shock
Trauma Center in a coma from which he was never revived. He died one week later from a fatal spinal injury after also experiencing complete cardiopulmonary arrest. His spine was $80 \%$ severed at his neck.

Freddie Gray never made it to prison. His incarceration began and ended in the back of a van.

At least he never made it to prison that, final, time. In fact, Gray, had a long criminal record, mainly for minor drug offenses and minor crimes (trespassing; illegal gambling; destruction of property), and had spent time in prison in 2009 for drug possession. In this respect he was entirely representative, one of the millions of young African Americans who routinely cycle through what we call "the criminal justice system"- which for them is the system of deprivation, harassment, detention, arrest, imprisonment, release, and further deprivation. What happened to Freddie Gray was exceptional only in the extremity of his quick and violent end and the public attention, and outrage, that his end provoked.

Even here there was something disturbingly banal about this episode, coming as it did only months after the controversial August 2014 fatal police shooting of Michael Brown, an unarmed African American teenager in Ferguson, Missouri; and the September 2014 fatal police shooting of Tamir Rice, a twelve-year-old African American child, in Cleveland, Ohio; and days after the April 5, 2015 fatal police shooting of Walter Scott, an unarmed African American man with a broken taillight, in North Charleston, South Carolina; and so on. History may sometimes repeat itself in the manner described by Karl Marx: "first as tragedy, then as farce." But there is nothing farcical about the regularity with which unarmed African Americans recently have been shot dead by police officers in American cities. Indeed, while it is common to refer to these killings, and the broader situation in which they take place, as "tragic," it is also becoming increasingly common to speak about these things in a language beyond tragedy and farce- the language of justice and injustice, a discourse in which questions of human rights and democratic legitimacy come to the fore.

We started planning this issue of Perspectives 15 months ago, long before the most recent episodes recounted above, 
but long after activists, legal scholars, and some social scientists began calling attention to the situation in question. We did this for two reasons: because we were aware of a substantial number of new or forthcoming books on the topic written by political scientists, and indeed had received a few article submissions on the topic as well; and because the topic is important, for politics, especially in the United States, and for American political science.

For a concise description of the situation in question, I turn to The Growth of Incarceration in the United States: Exploring Causes and Consequences (2014), a 435-page report of the National Academy of Sciences' National Research Council supported by grants from the John D. and Catherine T. MacArthur Foundation and the U.S. Department of Justice:

From 1973 to 2009 , the state and federal prison populations that are the main focus of this study rose steadily, from about 200,000 to 1.5 million, declining slightly in the following 4 years. In addition to the men and women serving prison time for felonies, another 700,000 are held daily in local jails.... The U.S. penal population of 2.2 million adults is the largest in the world. In 2012, close to 25 percent of the world's prisoners were held in American prisons, although the United States accounts for about 5 percent of the world's population. The U.S. rate of incarceration, with nearly 1 of every 100 adults in prison or jail, is 5 to 10 times higher than rates in Western Europe and other democracies" (p. 2).

The facts offer a fascinating perspective on the longdiscussed theme of so-called American Exceptionalism. And yet if these facts speak quite loudly, the conventional political science approaches to the study of American politics have until fairly recently been rather inaudible on the topic. In the past 10 years the so-called "Big Three" of American political science journals, that is, the top journals publishing conventional empirical research on American politics-the American Political Science Review, American Journal of Political Science, and Journal of Politics-have published no more than a handful of pieces combined related to the topics of policing and incarceration. Do the math. That is five pieces out of many hundreds of published articles. At thousands of institutions of higher learning in the United States, undergraduate students regularly take political science courses on "Introduction to American Politics." Open up any major textbook on the topic. You will find chapters on all the standard topics - federalism and the U.S. Constitution; Congress, the presidency, the courts; interest groups and political parties and elections and campaigns; the bureaucracy and the media. Some of these fine books will contain a very short section on "the criminal justice system." How many of these books contain chapters or even sections on "The American Politics of Mass Incarceration?" or "Police Brutality, Racism, and Urban Politics in the United States" or "Political Disenfranchisement and the New Jim Crow?" or "The Criminal Injustice System?"
Perhaps there is a good reason for this. Perhaps these features of what we call "American politics" are fairly marginal, and thus inessential, relative to those features of American politics typically considered essential, things like "how a bill becomes a law" or "how federalism works" or "how presidents shape public opinion?" Perhaps. Really? And in any case, why? How does it get decided that some things are central themes of U.S. politics and other things are peripheral? As I write this Introduction, two things are clear. One is that many people in the United Statescitizens, community activists and organizers, legal professionals, economists, journalists, and even some law enforcement professionals - are coming to see that what might once have been seen as peripheral is in fact increasingly central, a serious normative blight on and political dysfunction of American democracy. The second is that there is a rich, exciting, and growing attention to these themes on the part of political scientists. This work might not (yet) represent the new mainstream of American politics research. But it surely represents a major development that substantially invigorates the study of American politics.

The purpose of this issue of Perspectives on Politics is to feature this work, because it is excellent work and because it highlights themes that really ought to be more central to the understanding of U.S. politics and of politics more generally. Indeed, some of these themes do figure prominently in political science research-but typically with regard to discussions of "authoritarianism" or "repressive regimes" in places like Africa or the Middle East. It is now clear that a truly general, comparative, and nonparochial political science must account for the fact that the topics of policing, police brutality, incarceration, and repression more generally are not limited to authoritarian regimes. They also play an important role in the functioning of polyarchal, so-called democratic regimes. Getting serious about these things is consistent with other important developments in the study of U.S. politics, most especially attention to the limits of pluralism and the politics of growing inequality, themes we have highlighted in recent issues. At the same time, I cannot help but think of Crosby, Stills, Nash, and Young's song "Déjà vu," for we surely have been here before. I am reminded of the famous 1968 Report of the National Advisory Commission on Civil Disorders (The Kerner Commission Report); and the 1971 Attica Prison riot in New York; and the early 1970’s revelations about the FBI's COINTELPRO initiative (Counterintelligence Program); and more generally, what Alan Wolfe referred to in his 1973 book of the same name as The Seamy Side of Democracy: Repression in America.

One spur to the planning of this special issue was the recent publication of three interesting and important books on the politics of massive arrest and imprisonment and its implications for U.S. democracy: Marie Gottschalk's Caught: Race, Neoliberalism, and the 
Future of the Carceral State and American Politics; Amy Lerman and Vesla Weaver's Arresting Citizenship: The Democratic Consequences of American Crime Control; and Naomi Murakawa's The First Civil Right: Racial Liberalism and the Rise of Prison America. While we have been organizing Critical Dialogues for years, this issue contains our journal's first Critical Trialogue, bringing these authors together in a broad discussion of what has come to be called "The Carceral State." (Our Critical Dialogue between Andrew Dilts, author of Punishment and Inclusion: Race, Membership, and the Limits of American Liberalism, and Banu Bargu, author of Starve and Immolate: The Politics of Human Weapons, presents an overlapping discussion of what we might call the comparative politics of imprisonment).

In speaking of the carceral state, scholars such as Gottschalk, Lerman and Weaver, and Murakawa intend to call attention to the ways that punitive policies of mass incarceration form something of an interlocking system, grounded in historical path dependencies and possessing a reinforcing "logic" of their own. They also wish to underscore the fact that this system is enabled by - and also seriously constrains, distorts, and influences-the "normal" functioning of "democracy" in the United States. This issue of Perspectives contains two terrific articles expanding on this theme. Rebecca Thorpe's "Perverse Politics: The Persistence of Mass Imprisonment in the Twenty-First Century" argues that "the persistence of mass incarceration in a period of reduced crime, fiscal constraints, and less punitive public attitudes is reinforced by a particularly perverse form of democratic politics, where a crucial subset of lawmakers and districts vote to impose harsh and degrading punishments on another subset of society because they experience short-term political and economic gains from carceral expansion." Like Gottschalk, Thorpe explains how a system of policy feedbacks reinforces this state of affairs: "I argue that there are more deep-seated, but less visible, obstacles to dismantling the penal system that neither reform-minded advocates nor previous researchers fully address. Just as mass incarceration disproportionately affects poor black and Hispanic men located in segregated urban districts, swelling imprisonment rates also produced a historically unprecedented trend: prisons became a 'growth industry' in rural America. When new forms of punishment criminalized behaviors likely to flourish in urban ghettoes isolated from formal labor markets, policymakers also capitalized on demand for prison infrastructure in order to bring jobs and capital to many economically distressed, rural communities. ... [W] hat began as a politically expedient wave of rural prison development may have inadvertently unleashed a self-reinforcing punishment regime that is uniquely resistant to self-correction."

If Thorpe centers her analysis on the ways that prison construction and operation bring benefits to many local communities and corporate interests, Mary Fainsod Katzenstein and Maureen Waller's "Taxing the Poor: Incarceration, Poverty, Governance, and the Seizure of Family Resources" focuses on the way this prison system adds insult to injury for prisoners and their poor and often minority families, who are subjected to "a process of outright 'seizure,' [whereby] the state now exacts revenue from low-income families, partners, and friends of those individuals who in very large numbers cycle in and out of the nation's courts, jails, and prisons ... to help finance the state's own coffers, including the institutions of the carceral state itself." Katzenstein and Waller document the ways that an "inverted welfare system" imposes a range of financial charges - for inmate services, for phone and video contact between inmates and their families_- "on the mother, grandmother, partner, sister, daughter, or friend (mostly women) of the incarcerated poor (mostly men) to subsidize the carceral state." Drawing on the work of Suzanne Mettler, they describe these practices as a perverse form of "submerged state" in which "state entities, in collaboration, often, with their corporate partners, act knowingly but in unseen ways to leverage money from families, partners, and friends of the prospectively, currently, or formerly incarcerated poor."

As these scholars make clear, such practices not only reproduce the long-term disenfranchisement of the incarcerated and postincarcerated (see Mary Fainsod Katzenstein, Leila Mohsen Ibrahim, and Katherine D. Rubin, "The Dark Side of American Liberalism and Felony Disenfranchisement," Perspectives on Politics, December 2010). They also have serious class distributional implications, and represent one element of a broader neoliberal regime of "poverty governance." (Here I also recommend a March 2015 Institute for Policy Studies Report by Karen Dolan and Jodi Carr, The Poor Get Prison: The Alarming Spread of the Criminalization of Poverty, and also Jeffrey Reiman's 1979 The Rich Get Richer and the Poor Get Prison, now in its tenth edition.) As this literature also makes clear, the "carceral state" is profoundly racialized at every point, from police profiling to apprehension to arrest to prosecution to conviction to imprisonment to release- a point underscored by the title of the book frequently credited with having spurred current legal and social-scientific inquiry into the topic, Michelle Alexander's 2010 The New Jim Crow: Mass Incarceration in the Age of Colorblindness. This interpenetration of class and race has been made even more vividly clear by the recent police killings of black men noted in my introductory paragraph, and has been dramatically registered by the slogan that went viral in the wake of the 2013 acquittal of the killer of Trayvon Martin: "Black Lives Matter." The point is also made, in understated fashion, by the United States Department of Justice Civil Rights Division's 102-page "Investigation of the Ferguson Police Department": 
Ferguson's law enforcement practices are shaped by the City's focus on revenue rather than by public safety needs. This emphasis on revenue has compromised the institutional character of Ferguson's police department, contributing to a pattern of unconstitutional policing, and has also shaped its municipal court, leading to procedures that raise due process concerns and inflict unnecessary harm on members of the Ferguson community. Further, Ferguson's police and municipal court practices both reflect and exacerbate existing racial bias, including racial stereotypes. Ferguson's own data establish clear racial disparities that adversely impact African Americans. The evidence shows that discriminatory intent is part of the reason for these disparities. Over time, Ferguson's police and municipal court practices have sown deep mistrust between parts of the community and the police department, undermining law enforcement legitimacy among African Americans in particular.

The politics of policing in the United States, and especially the racial politics of policing, is a second major theme featured in this issue. As Keally McBride writes in "Punitive Politics in the United States: The End of an Era?": "Policing is one of the most frequent ways that the physical movement of people is regulated, and the authority of the state is made visible, hence it is one of the most important institutions of democracy and citizenship in our country that has been largely ignored by political scientists." McBride makes clear that this is a topic no longer being so ignored, reviewing three important new books on the ways that "criminal justice" casts a dark shadow on the lived experience of citizenship for many African Americans in urban America: Traci Burch's Trading Democracy for Justice: Criminal Convictions and the Decline of Neighborhood Political Participation; Charles R. Epp, Steven Maynard-Moody, and Donald P. HaiderMarkel's Pulled Over: How Police Stops Define Race and Citizenship; and Alice Goffman's On The Run: Fugitive Life in an American City. Vincent Hutchings's review essay, "Race, Punishment, and Public Opinion," on The Sentencing Project's 2014 report Race and Punishment: Racial Perceptions of Crime and Support for Punitive Policies, also centers on "how racial prejudice contributes to the maintenance of a biased and punitive criminal justice system." As Hutchings concludes: "perhaps the chief advantage of the Sentencing Project Report is that it draws our attention to persistent racial disparities in the criminal justice system even as it highlights the role that public opinion plays in sustaining these inequities. Needless to say, this comes at an especially important time given the unprecedented media attention that has been devoted to allegations of police misconduct in African American communities. As indicated above, there is at least some evidence that various forms of racial prejudice as well as the dehumanization of African Americans can help to explain these encounters. Political scientists who examine issues of criminal justice would do well to consider both sources of bias, especially dehumanization."

Lynda G. Dodd's article "The Rights Revolution in the Age of Obama and Ferguson: Policing, the Rule of Law, and the Elusive Quest for Accountability" addresses a related question: What are the means of holding police officers, and indeed police forces, accountable for civil rights violations? As Dodd writes: "Much of the public debate [has] focused on the criminal liability of the police officers involved and the role of local grand juries in seemingly shielding these officers from criminal prosecution, but local criminal prosecutions are not the only legal mechanism for holding police officers and other government officials accountable. Protestors and civil rights leaders also repeatedly called on the Justice Department to pursue federal criminal prosecutions and broader civil rights investigations. In this article, I examine another mechanism to hold these police officers accountable: civil actions, often referred to as 'constitutional tort' lawsuits, for monetary damages under 42 U.S.C. $\$$ 1983 , the federal statute providing a civil cause of action in federal courts for constitutional rights violations." Dodd analyzes recent Rehnquist and Roberts Supreme Court decisions that limit Section 1983 litigation, placing these decisions in the context of earlier cases from the 1970s and 1980s limiting the gains associated with the "rights revolution" of the 1960 's. She argues that a set of recent "[legal] doctrines taken together-limits on suits against states and state officials, qualified immunity, supervisory immunity, and the policy or custom requirement-create an interlocking set of hurdles for plaintiffs seeking to hold police officers and other government officials accountable for constitutional violations."

As recent events in Ferguson, Missouri, and Baltimore, Maryland, make clear, such accountability is an issue not simply for directly affected individuals and their families, but for entire communities, for entire cities, and indeed for the nation as a whole. Arguably nothing less than the rule of law and democratic equality are at stake. As these events also make clear, policing looms large not simply as a means of effecting "criminal justice" but also as a means of "maintaining law and order" in the face of actual and even potential public demonstrations, that is, as a means of "crowd control" and regulation of public space through intimidating displays of massive force and through the actual exercise of coercive power. This issue of Perspectives contains three review essays on this theme. Christopher Coyne's "The Militarization of Policing and the Future of American Politics" reviews journalist Radley Balko's Rise of the Warrior Cop: The Militarization of America's Police Force, a widely discussed history of policing in the United States, which links recent police mobilizations of armored vehicles and automatic weapons and military-grade Kevlar vests to a sequence of developments, from the 1967 creation of SWAT units in Los Angeles to deal with the Watts riots, to the so-called War on Drugs of the 1980s, to the current "War on Terror" supported by the post $9 / 11$ Department of Homeland Security (DHS). As Coyne writes: "One of the insights emerging from Balko's analysis is that the provision of what at first might appear to be 
productive state activities—i.e., policing — may actually be predatory and unproductive by undermining the liberty and freedom of domestic citizens.... [T] he issue of police militarization requires studying the effects of what happens when perpetual wars are carried out on the homeland."

If Coyne, following Balko, furnishes a broadly libertarian perspective on these developments, Alex Gourevitch's "Police Work: The Centrality of Labor Repression in American Political History" offers a left perspective, linking the militarization of policing to the prevalence of class conflict in American political development:

The industrial strike has been one historical expression of that conflict of interests in capitalist society, and it has regularly been met with force. That is because a capitalist society is a class society. Therefore, it is a society that has needed not just the occasional enforcement of the law but the regular application of force. The Smithian promise of a limited state, restricted to catching criminals and enforcing the law, has been something more like a myth. The policing of workers has been an indispensable feature of capitalist development. Nowhere has this been clearer than the United States, where pre-capitalist forms of authority were weaker than in Europe and therefore less available as forms of social control. A society based on labor contracts is a society that, as it turns out, needs police willing to engage in a wide range of repressive interventions. ... Indeed, such repressive interventions have played a crucial role in the course of U.S. history and in the unfolding of what is called in political science "American political development." And yet, strangely, such interventions, their histories, and their institutional conditions, receive little attention in standard textbook treatments of American politics, not to mention the vast and ever-growing scholarship in the subfield of U.S. politics, which tends to focus on Congressional dynamics, campaigns and elections, judicial decision-making, and bureaucratic collective action dilemmas. It is tempting to say that this is the domain of "normal politics." But for many U.S. citizens—along with a great many undocumented residents subject to detention and deportation-it is indeed the police that is the most palpable and first face of power they experience. Recently, these matters have broken violently into public life, in cities like Los Angeles, California, Ferguson, Missouri, Cleveland, Ohio, Tulsa, Oklahoma, North Charleston, South Carolina, and Staten Island, New York. As these events have come to the fore, a small but growing body of political science scholarship about policing and incarceration has also grown in prominence. Much of this literature focuses, rightly, on questions of race. But as I will show, in order to understand the emergence of policing in the U.S., we must understand the politics of class and capitalism.

William Smith's "Policing Democracy: Race, Riots, and Protest" offers a comparative perspective, juxtaposing Cathy Lisa Schneider's Police Power and Race Riots: Urban Unrest in Paris and New York and the International Network of Civil Liberties Organization's 2014 "Take Back the Streets": Repression and Criminalization of Protest Around the World. While Schneider's book centers on the discriminatory policing of race riots in France and the United States, the INCL Report documents a broader global tendency of police forces to restrict public space and limit public assembly through street closures, mass arrests, unlawful detentions, and the deployment of toxic chemicals against both protesters and civilian bystanders.

If the theme of incarceration naturally implicates the theme of policing, the theme of policing naturally implicates the broader theme of "domestic security" and "national security" more generally. Our current issue also contains two pieces dealing directly with this theme. Tyler Curley's article "Models of Emergency Statebuilding in the United States" discusses "the contours of institutional change during past times of emergency-what can be called emergency statebuilding" in U.S. political history. Curley outlines the strengths and weaknesses of three dominant approaches, and proposes a fourth view, "discursive institutionalism," that integrates the advantages of each. As he sums up his argument: "the shift to lasting crisis governance in the United States can be understood as part of a wider transition in the role of planning expertise beginning in the 1930s. Rather than assuming that emergencies are exogenous shocks to a stable structure, this approach demonstrates how discourse and knowledge about planning incorporated future emergency needs into the existing institutional system so that temporary, ad hoc measures were no longer necessary. This thread can be traced all the way through World War II mobilization, Cold War technocratic preparations for civil defense, and post-9/11 efforts to thwart terrorism."

In his important book $A$ Theory of Militant Democracy: The Ethics of Combatting Political Extremism, Alexander S. Kirschner proposes a "self-limiting theory of militant democracy" that is based on three "interlocking principles": the participatory principle, the principle of limited intervention, and the principle of democratic responsibility. Kirschner argues that there are crisis situations where democratic states can legitimately constrain democracy in the interests of democracy; but such "militant democracy" is aimed at maximizing participation, should only occur in exceptional circumstances, and should involve open, public acknowledgment of the costs of intervention and its temporary quality. Our symposium on his book offers commentaries by Giovanni Capoccia, Nomi Clare Lazare, Cas Mudde, and Takis Pappas on the tensions between appeals to security, law and order, and the need to combat "political extremism," and the requirements of democratic rule of law, and the possible ways of reconciling these tensions.

Peter Andreas's "International Relations and the Illicit Global Economy" also deals with the themes of security and the rule of law. As Andreas writes: "The illicit global economy involves a diverse cast of non-state actors: drug dealers, clandestine arms traders, sex traffickers, money launderers, maritime pirates, coca and poppy farmers, copycats, child pornographers, black market kidney brokers, embargo busters, and wildlife smugglers, to name just a few. The state actors are equally diverse: cops, customs inspectors, border guards, prosecutors, financial crimes investigators, undercover agents, and so on. One 
thing that all of these state and non-state actors have in common is that they have traditionally been almost entirely overlooked by mainstream International Relations (IR) scholars." Andreas sets out to remedy this, reviewing a number of important recent books on the topic and demonstrating the importance of global crime and policing for domestic political systems and the international order.

The contents of this issue of Perspectives highlight, in different ways, the centrality of what Louis Althusser once called "the repressive apparatuses of the state" to "normal" politics in liberal democracies and especially to politics in the United States. As Curley's piece makes clear, the links between the logics of domestic "law and order" and "national security" have become especially strong in the United States during the post-9/11 period, shaping practices of domestic policing, drug enforcement, immigrant detention and deportation, and the surveillance of "suspects" in the "War on Terror." At the same time, as many of the other pieces in this issue make clear, these practices are rooted in a longer history that is heavily inflected by class, gender, and especially race. Not all of the features of "American exceptionalism" are benign. And as recent events indicate, it is increasingly clear that these less benign features of American politics are rising to the surface of public attention and concern because they are in many ways "dysfunctional," but also because they are being contested. And as this issue as a whole demonstrates, many U.S. political scientists are doing interesting and important work on these topics that surpasses the categories and concerns of standard textbook accounts.

This work involves new forms of analyzing and theorizing, but also new forms of scholarly praxis designed to publicize and to contest abuses associated with regimes of policing, detention, and incarceration. Discussion of such praxis is also featured in this issue.

In "Forensic Intelligence and the Deportation Research Clinic: Toward a New Paradigm," Jacqueline Stevens describes the approach to research, litigation, and publication developed by her Deportation Research Clinic at Northwestern University. "The Clinic," she writes, "is more than a conventional scholarly research enterprise. It is a form of praxis that collaborates with those brutalized by deportation proceedings to procure and produce information for redress of government misconduct, especially that experienced as injustice, and then documents outcomes. ... [Clinic projects] are all inspired by a forensic approach to political inquiry that places a premium on research that uses publications as well as lawsuits to critically expose unlawful operations of a U.S. deportation regime that typically protects its perpetrators by deporting the evidence of their malfeasance, including U.S. citizens, whom Immigration and Customs Enforcement (ICE) has no legal authority to detain." Securing access to individuals caught in the labyrinthine system of detention, prying loose restricted information from the government via
Freedom of Information Act requests, and contesting the detention and deportation practices of a dense and unaccountable bureaucracy are not the kinds of activities one typically imagines when thinking about the practice of political science. (For a more conventional scholarly discussion, see this issue's Critical Dialogue between Bridget Anderson and Joseph H. Carens on the ethics of immigration control and detention.) And yet for some colleagues, such activities are wholly continuous with more conventional practices of research, publication, teaching, and "professional service."

Working in prisons is also not the kind of activity one typically imagines when answering the question "What do political scientists do?" In "Democracy and Education Behind Bars: The JCI Prison Scholars Program in Maryland," Joshua Miller reflects on the JCI Prison Scholars Program (JCIPSP), a nonprofit organization that supports faculty from throughout the D.C. and Maryland region to teach college-level courses at JCI, a Maryland state prison in Jessup. As Miller writes:

The hope that a college education can offer is an immeasurable
benefit, a path to success where most others are foreclosed.
Women and men returning from prison face significant
discrimination at every turn, despite having paid their debt
and served their time. .. Reducing future incarceration is not
our primary reason for working with this population. We believe
that the expansion of our students' capacities and knowledge is an
intrinsic good, and we act on that belief by working with many
who have long-term and life sentences. Our goal is to model and
enable life-long learning. As we put it in our mission statement:
the liberal arts are the techniques of freedom. And they are
techniques that can be learned and applied both within prisons
and outside. Our students are leaders in their gangs, in their
churches, and in their antiviolence and conflict resolution
groups. .. We have to understand our disenfranchised students
as citizens even though they cannot vote, and thereby expand our
own sense of what citizenship enables and requires: they are
collaborators in the constitution of their shared world, and
ultimately of ours.

It is worth noting that such prison education initiatives are springing up across the United States, and that political scientists, including contributors to this issue of our journal, often play crucial roles as educators. (Editorial board member Marc Morjé Howard participates in the JCI Program, and has also taught tennis in prisons, as he reported in his June 16, 2011, Sports Illustrated article "Lessons in Integrity with San Quentin State Prison's Tennis Team"; and board member Mary Fainsod Katzenstein is one of the leaders of the Cornell University Prison Education Program).

If Stevens underscores the documentary/forensic uses of political science research, and Miller underscores the pedagogical and political importance of prison education, Georgia Warnke's "Philosophical Hermeneutics and the Politics of Memory" underscores the important ways that the political inquiries undertaken by empirical researchers and by normative political theorists can 
contribute to greater public understanding about the history of racial violence, repression, segregation, and discrimination in the United States. Warnke notes that important features of the history of racial dispossession and injustice in the United States-lynchings, race riots such as the Tulsa riot of 1921, property seizures and forms of coercive residential and racial segregation-are essentially absent from the teaching of American history and from public memory. Drawing upon the approach to "philosophical hermeneutics" developed by Hans-Georg Gadamer, Warnke argues that "a hermeneutical perspective can contribute to serious discussion among U.S. political scientists and political educators about the links between racial inequality and historical understanding and its absence." Two discussions featured in this issue-the Critical Dialogue between Neil Roberts, author of Freedom as Marronage, and Jimmy Casas Klausen, author of Fugitive Rousseau: Slavery, Primitivism, and Political Freedom, and Desmond Jagmohan's review of Edward E. Baptist's The Half That Has Never Been Told: Slavery and the Making of American Capitalismattempt to address and to remedy such historical misunderstandings.

Lawrie Balfour's "Ida B. Wells and 'Color Line Justice': Rethinking Reparations in Feminist Terms" can indeed be read as an extended example of the kind of critical hermeneutic outlined by Warnke. Balfour begins with the 2005 U.S. Senate resolution apologizing for the Senate's historical obstruction of federal legislation to outlaw lynching. She suggests that despite appearances, "the Senate resolution exemplifies most Americans' continuing unwillingness to grapple with the living legacies of slavery and Jim Crow. ... A closer look at the context and text of the Senate resolution shows how an effort to produce a 'new understanding [of U.S. history], on which improved racial relations can be forged' could forestall public confrontation with either the full weight of the past or its implication in the conditions of the present." She then turns to Ida B. Wells, who was invoked, in a casual way, in the Senate resolution, arguing that if we take Wells seriously, we will arrive at a much more substantial, radical, and democratic critique of American racism.

Wells was an extraordinary civil rights and women's rights activist. Born a slave in Mississippi in 1862, she experienced firsthand the scars of slavery, and grew up amid the violence and reaction of post-Reconstruction America. Orphaned as a young teenager, she struggled to obtain an education, eventually studying at Fisk, Le Moyne, and Rust Colleges. She worked as an elementary school teacher, but became famous as an investigative journalist writing about lynching and racial violence. Co-owner and editor of the Memphis Free Speech and Headlight, an antisegregationist newspaper, in 1892 she published a pamphlet entitled Southern Horrors: Lynch Law in All Its Phases and in 1895 published The Red
Record: Tabulated Statistics and Alleged Causes of Lynching in the United States, a 100-page pamphlet describing lynching in the United States since the Emancipation Proclamation. Wells was an activist and publicist on behalf of racial equality and human rights. She was also a "forensic researcher" in the sense outlined by Jacqueline Stevens, documenting abuses and indeed functioning as a kind of lay empirical political scientist. As Balfour writes:

Wells's assessment of the political and economic causes and consequences of lynching lays bare the central role of antiblack violence in the constitution of race and gender in the U.S., and it offers a model of democratic thinking that defies the presuppositions of the "postracial" age. Indeed ... Wells's political thought offers a valuable resource for reparations arguments that are both antiracist and feminist. ... Insisting that democratic life depends on a willingness to investigate the roots of injustices taking place in the present and to reckon with their links to policies and citizenly habits that have been sedimented over generations, Wells's writings are historical, critical, and reconstructive. More specifically, Wells provides an analysis of the relationship between past practices and present-day instantiations of white supremacy, that both discerns the entanglement of racialized forms of political and economic power with gender and sexuality, and. . .joins a concrete list of things that citizens can do to a broad account of democratic responsibility. . . [R] evisiting her analysis of the savage rise of Jim Crow from the embers of slavery offers important theoretical resources for situating and understanding the devaluation of black life and citizenship more than a century after she wrote and fifty years after the key legislative triumphs of the Civil Rights Movement.

On Wednesday, April 28, 2015, Hillary Clintonformer first lady of the United States, former U.S. senator, former U.S. secretary of state, and current frontrunner for the Democratic nomination in the U.S. presidential election of 2016 - gave a widely quoted speech at Columbia University in New York. Listing by name the litany of recent police killings noted at the beginning of this Introduction, she insisted that "We have to come to terms with some hard truths about race and justice in America":

There is something profoundly wrong when African American men are still far more likely to be stopped and searched by police, charged with crimes, and sentenced to longer prison terms than are meted out to their white counterparts. There is something wrong when a third of all black men face the prospect of prison during their lifetimes. And an estimated 1.5 million black men are "missing" from their families and communities because of incarceration and premature death. There is something wrong when more than one out of every three young black men in Baltimore can't find a job. There is something wrong when trust between law enforcement and the communities they serve breaks down as far as it has in many of our communities. We have allowed our criminal justice system to get out of balance. And these recent tragedies should galvanize us to come together as a nation to find our balance again. ... It's time to end the era of mass incarceration.... We need a true national debate about how to reduce our prison population while keeping our communities safe.

The work featured in this issue of Perspectives suggests that such a debate is likely to come up against some serious 
obstacles, for there is a history and a politics behind "the carceral state," and the broader system of policing, detention, and "security" of which it is a part. Such a politics may be "perverse." But it is no less real for this. At the same time, this system is now being forced to the forefront of public attention. The kind of political science contained below has much to contribute to public discussion of these issues. 


\section{Statement of Mission and Procedures}

Perspectives on Politics seeks to provide a space for broad and synthetic discussion within the political science profession and between the profession and the broader scholarly and reading publics. Such discussion necessarily draws on and contributes to the scholarship published in the more specialized journals that dominate our discipline. At the same time, Perspectives seeks to promote a complementary form of broad public discussion and synergistic understanding within the profession that isessential toadvancing scholarship and promoting academic community.

Perspectives seeks to nurture a political science public sphere, publicizing important scholarly topics, ideas, and innovations, linking scholarly authors and readers, and promoting broad reflexive discussion among political scientists about the work that we do and why this work matters.

Perspectives publishes work in a number of formats that mirror the ways that political scientists actually write:

Research articles: As a top-tier journal of political science, Perspectives accepts scholarly research article submissions and publishes the very best submissions that make it through our double-blind system of peer review and revision. The only thing that differentiates Perspectives research articles from other peer-reviewed articles at top journals is that we focus our attention only on work that in some way bridges subfield and methodological divides, and tries to address a broad readership of political scientists about matters of consequence. This typically means that the excellent articles we publish have been extensively revised in sustained dialogue with the editor-me-to address not simply questions of scholarship but questions of intellectual breadth and readability.

"Reflections" are more reflexive, provocative, or programmatic essays that address important political science questions in interesting ways but are not necessarily as systematic and focused as research articles. These essays often originate as research article submissions, though sometimes they derive from proposals developed in consultation with the editor in chief. Unlike research articles, these essays are not evaluated according to a strict, doubleblind peer review process. But they are typically vetted informally with editorial board members or other colleagues, and they are always subjected to critical assessment and careful line-editing by the editor and editorial staff.

Scholarly symposia, critical book dialogues, book review essays, and conventional book reviews are developed and commissioned by the editor in chief, based on authorial queries and ideas, editorial board suggestions, and staff conversations.

Everything published in Perspectives is carefully vetted and edited. Given our distinctive mission, we work hard to use our range of formats to organize interesting conversations about important issues and events, and to call attention to certain broad themes beyond our profession's normal subfield categories.

For further details on writing formats and submission guidelines, see our website at http://www.apsanet.org/ perspectives/ 